\title{
REQUIREMENTS AND ETHOS OF THE CHURCH MISSION IN SOCIETY AND ORTHODOX SPIRITUALITY ${ }^{1}$
}

Oana (căs. Nicolae) Pop*

\begin{abstract}
In a secular world and a desecrated society, asserting the Orthodox Church is a demanding task that imposes itself as a requirement of our days. Extending the life of Christ in the people and the Descent of the Holy Spirit gives birth to the Church as the ecclesial body of Christ and temple of the Holy Spirit, the achievement of personal salvation and deification by grace of believers. The missionary work of the Church is the result of clergy and of the faith of all people. The evolution of social and cultural life is not an "external" fact, but it is reflected in the internal evolution of the Church. The Church should be seen as a social place of the word that speaks of the fullness of the word "to exist" when it glorifies God.
\end{abstract}

Keywords: secularization, Church's mission, spirituality, communion, finding Christ

De două milenii Biserica trăieşte şi continuă cu succes opera mântuitoare a lui Iisus Hristos prin preoții săi, care vestesc cuvântul lui Dumnezeu, administrează Sfintele Taine şi îi conduc cu zel pe cei încredințaţi lor, prin trăirea în ,,comuniunea sfinților”,2. Este adevărat

\footnotetext{
${ }^{1}$ Cercetare finanțată prin proiectul „MINERVA - Cooperare pentru cariera de elită în cercetarea doctorală şi post-doctorală", cod contract: POSDRU/159/1.5/S/137832, proiect cofinanțat din Fondul Social European prin Programul Operaţional Sectorial Dezvoltarea Resurselor Umane 20072013 in cadrul Academiei Române, Filiala Cluj-Napoca.

* PhD candidate, Faculty of Orthodox Theology, „Babeş-Bolyai” University, Cluj-Napoca.

${ }^{2}$ Valer Bel, Misiunea bisericii în lumea contemporană, Cluj-Napoca, Edit. Renaşterea, 2010, p. 243.
} 
că între timp multe s-au schimbat şi continuă să se schimbe în această lume.

Scopul final al misiunii Bisericii este arătat de: „efortul nostru mereu crescând de a ne uni cu Tatăl prin harul divin redobândit de Hristos prin toate actele mântuirii obiective şi împărtăşit de Sfântul Duh, care odihneşte în trupul Său îndumnezeit, har pe care-l primim în Biserică, în Sfintele Taine, prin lucrarea ierarhiei bisericeşti sacramentale" ${ }^{3}$

\section{Biserica — stâlpul şi temelia adevărului}

Biserica nu poate fi cuprinsă, de fapt, pe deplin, într-o definiție, ea poate fi eventual descrisă de către cei care participă la viața ei în măsura împărtăşirii cu Sfintele Taine, prin care primitorii acestora se unesc cu Domnul, devenind pe această cale mădulare ale Bisericii lui Hristos şi unii altora. A ajunge astfel să cunoşti în ce anume constă ființa Bisericii implică o pătrundere înlăuntrul ei, ,întrucât doar trăind în ea şi cu ea eşti cuprins de lucrarea mântuitoare a lui Dumnezeu în Hristos care se prelungeşte prin ea",

Conform învăţăturii de credință ortodoxe, Biserica este Trupul Fiului lui Dumnezeu, Iisus Hristos ${ }^{6}$, Mântuitorul lumii, jertfit pe Cruce pentru viața şi eliberarea creației din sferele distructive ale păcatului, prelungit în istorie în toate persoanele botezate în numele Sfintei Treimi. În ființa ei, Biserica este şi va fi până la sfârşitul veacurilor ,taina adunării tuturor în Hristos, sau extinderea existenței lui

3 Mihai Himcinschi, Doctrina trinitară ca fundament misionar. Rela ia Duhului Sfânt cu Tatăl şi cu Fiul în teologia răsăriteană şi apuseană, AlbaIulia, Edit. Reîntregirea, 2004, p. 339.

4 Valer Bel, Unitatea bisericii în teologia contemporană. Studiu interconfesional-ecumenic, Cluj-Napoca, Edit. Limes, 2003, p. 7-8.

${ }^{5}$ Ibidem, p. 27.

${ }^{6}$ Ioan-Vasile Leb, Biserica ortodoxă şi societatea civilă, în vol. "Religia şi societatea civilă", Mircea Flonta, Hans Klaus Keul şi Jörn Rûsen (coord.), Bucureşti, Edit. Paralela 45, 2005, p. 117. 
Hristos în toți cei ce rămân în comunitatea ei"”, prin Duhul Sfânt, ca Cincizecime continuă, ea neputând fi decât ca „una şi unică după modelul unităţii tripersonale a lui Dumnezeu"s.

Mântuitorul Iisus Hristos ne atrage atenția că Biserica întemeiată pe jertfa Sângelui Său nu va putea fi biruită nici de porțile iadului. Lucru logic, deoarece Biserica este Trupul lui Hristos, El fiindu-i Capul, Providenţiatorul şi Călăuzitorul în istorie. "În dăruirea lui Hristos, fiecăruia în parte, precum şi comunităţii ca întreg şi în actul de dăruire al comunității, care, din puterea dăruirii lui Hristos, răspunde dăruirii Lui, se realizează cea mai strânsă unire a oamenilor cu Hristos şi întreolaltă",

Este de datoria fiecărui membru al Bisericii să se constituie în "piatră vie" la temelia acesteia prin ortodoxie (dreapta credinţă) şi ortopraxie (fapte bune). Ortodoxia şi ortopraxia trebuie să fie pentru viața fiecărui creştin coordonatele centrale ale vieții sale sacramentale, familiale şi sociale, adică o mărturisire neîntreruptă a lui Iisus Hristos ca Fiul lui Dumnezeu Celui adevărat şi veşnic, întrupat, Jertfit, înviat şi înălţat pentru transfigurarea omului, în special, şi a universului, în general. Mântuitorul Iisus Hristos ne învață că lumea va recunoaşte că suntem ucenicii Lui dacă vom avea dragoste unul către altul, comandament reclamat perpetuu în cântările şi rugăciunile Bisericii. Aceasta necesită o asumare deplină şi conştientă a misiunii profetice a creştinului ortodox în lume.

Împreună cu jertfele, rugăciunea formează partea indestructibilă a religiei şi sunt de mare importanță pentru păstrarea şi propăşirea credinței în Dumnezeu. Cele două forme de manifestare a credinței în divinitate se întâlnesc în toate religiile şi adevărata lor valoare pentru viața religioasă o aflăm în Sfânta Scriptură: „În spiritul cuvântului

\footnotetext{
7 Valer Bel, Unitatea bisericii în teologia contemporană. Studiu interconfesional-ecumenic, Cluj-Napoca, Edit. Limes, 2003 , p. 50.

${ }^{8}$ Ibidem, p. 70.

${ }^{9}$ Ibidem, p. 176.
} 
Scripturii rugăciunea este particulară şi comună, de aceea locaşul de cult mozaic va primi numele de «casă a rugăciunii»»"10.

\section{Ecumenism şi misiune în pocăință şi rugăciune}

Pornind de la modul de înțelegere al ecumenismului a Părintelui Iustin Popovici, am putea spune că se poate realiza numai prin înlăturarea oricărei urme de mândrie din partea oricărei Biserici sau denominațiuni creştine. „Există o singură cale de realizare autentică a adevăratului ecumenism ascetic şi eclezial...: căința şi întoarcerea tuturor indiferent de confesiune (deci, inclusiv a ortodocşilor înşişi!) la Ortodoxia integrală, respectiv la Evanghelia Dumnezeului-om (Mc 1, 15)" ${ }^{\prime 1}$.

Toți cei ce credem în Hristos, fără a avea o graniță sau vreo restricție, căutăm să creştem împreună spre a da roade vrednice de Stăpânul nostru.

„Misiunea Bisericii dată de Hristos şi realizată de Sfinții Părinți este aceea de a face să prindă rădăcini şi de a cultiva în sufletul poporului simțământul şi cunoştința faptului că fiecare membru al Bisericii Ortodoxe este o persoană catolică (sobornicească, universală), o persoană veşnică şi divino-umană; că este al lui Hristos şi, pentru aceasta, frate al tuturor oamenilor şi slujitor al tuturor oamenilor şi făpturilor”, ${ }^{\prime 2}$.

Misiunea nu se poate realiza fără rugăciune, credință personală şi dorință de a împărtăşi şi altora din binefacerile „Cinei lui Hristos”. Ea s-a început sub auspiciile rugăciunii şi s-a încheiat cu închegarea unei comunităţi ce practică rugăciunea şi „,frângerea pâinii”".

Rugăciunea îşi are rolul său bine stabilit atât în cultul public al Bisericii, cât şi în cultul personal al credinciosului. Prin rugăciune şi

\footnotetext{
${ }^{10}$ Emilian Cornițescu, Rugăciunea, în „Glasul Bisericii”, Anul L, nr. 4-6, iuliedecembrie, 1991, p. 26.

${ }^{11}$ Iustin Popovici, Omul şi Dumnezeu-Om, Abisurile şi culmile filozofiei, traducere Ioan Ică şi Ioan Ică jr., Sibiu, Edit. Deisis, 1997, p. 23.

${ }^{12}$ Ibidem, p. 76.
} 
pocăință marii sfinți ai Bisericii au ajuns la îndumnezeire, la unirea cu Dumnezeu. Ei au reprezentat şi reprezintă un model viu de trăire a rugăciunii în Hristos, Domnul nostru.

Misiunea este partea fundamentală a ființei Bisericii, căci propovăduirea Evangheliei lui Hristos la toate neamurile şi chemarea la „,reconciliere prin pocăință şi botez”" ${ }^{13}$ este o vocație ecclezială apostolică.

'În misiunea ei, Biserica este chemată să descopere semnele cuvântului lui Dumnezeu; formarea unei comunităţi autentice la nivel local, care să includă pe toți, fără nici o deosebire de sex, vârstă sau profesie şi care să pună accentul pe relațiile umane personale, redescoperirea unei comunităti tămăduitoare de susţinere şi de iubire activă..."14

Misiunea pe care Hristos a încredințat-o Bisericii Sale este în primul rând este de ordin religios ${ }^{15}$, bineînțeles, fără a neglija componentele sau reverberațiile politice, economice şi sociale ale misiunii.

"Noi trebuie să trăim în Hristos, legătura cu Tatăl sub lucrarea Duhului Sfănt. Ne vom simți atunci ca unii asupra cărora se odihneşte Duhul Sfânt aşa cum se odihneşte şi asupra Fiului. Prin darul Duhului Sfânt lucrează în Biserică şi în noi energiile Duhului Sfânt, energiile necreate aşa cum le-au numit unii Sfinții Părinți ai Bisericii . “16

\section{Etos misionar}

De-a lungul istoriei sale, Ortodoxia a dobândit un etos misionar specific, care nu poate fi înțeles fără a lua în considerare o

\footnotetext{
${ }^{13}$ Ioan Bria, Dicționar de teologie ortodoxă, București, Edit. Institutului Biblic şi de Misiune a Bisericii Ortodoxe Române, 1994, p.254.

${ }^{14}$ Nifon Mihăiță, Misiologie Creştină, Editura ASA, Edit. Universității Valahia din Târgovişte, 2001, p. 36.

15 Paul Evdochimov, Iubirea nebună a lui Dumnezeu, Bucureşti, Edit. Anastasia, 1993, p. 187.

${ }^{16}$ M. Costa de Beauregard, Mica dogmatică vorbită, traducere de Dumitru Stăniloae, Sibiu, Edit. Deisis, 1995, p. 31.
} 
serie de noțiuni teologice, instituții bisericeşti şi realități sociale, cum ar fi: Biserica locală, simfonie politică, autocefalie, asceză, filantropie socială, etc. Acest spirit misionar a fost determinat de circumstanțe istorice, adesea nefavorabile, în care Ortodoxia a fost nevoită să se restrângă la pastorație internă şi cult, la protejarea membrilor săi, fără libertatea unei misiuni externe de anvergură.

Sub raport sociologic, Biserica a exprimat vocea celor care suferă şi a formulat protestul lor împotriva nedrepțăilor de orice fel. Odată cu organizarea lor independentă, Bisericile locale s-au identificat din ce în ce mai mult cu istoria, cultura şi destinul unei naţiuni particulare. Întreaga lor misiune s-a exprimat adeseori în termeni de menținere a identității etnice şi de apărare a unității acelei națiuni. Obiectul misiunii ortodoxe nu a fost acela de a cuceri cu orice preț noi zone geografice creştine, adică universalitatea exterioară, ci mai degrabă de a ține poporul credincios într-o neîntreruptă continuitate fizică şi istorică a credinței. Biserica s-a extins odată cu naşterea şi afirmarea unei noi generații.

Secularizarea este un fenomen care determină deplasarea centrului de gravitate al vieții şi culturii de la Dumnezeu la om, acceptarea lumii ca realitate autonomă şi independentă de Dumnezeu. „Secularizarea plasează ființele umane în centrul creației şi le face scopul ultim al acestei lumi şi a istoriei. Umanitatea nu este stăpâna creației, este doar administratoarea ei, vrea conducerea lumii printr-o bazare pe sine" ${ }^{" 17}$.

Dumnezeu a fost scos din lume, pentru că oamenii au vrut să se aşeze conducători în locul Lui. Ca să se poată justifica locul pe care îl are omul pe pământ, s-au pus bazele acestei filosofii, pentru a da posibilitatea omului să devină autonom în raport cu Dumnezeu.

Putem spune chiar că ideile secularizării, au fost lansate de Fericitul Augustin (sec.V), fiind primul care a spus că lumea naturală funcționează ca o lume independentă, pentru că Dumnezeu rămâne dincolo de lume. Era influențat de o erezie mai veche, de care nu

${ }^{17}$ Mihai Himcinschi, Biserica în societate. Aspecte misionare ale Bisericii $\hat{\imath} n$ societatea actuală, Alba Iulia, Edit. Reîntregirea, 2006, p. 118. 
putea să se detaşeze - maniheism - şi a trebuit să despartă lumea de Dumnezeu şi să ajungă în cele din urmă la teoria predestinaţiei ${ }^{18}$.

Secularizarea îşi are originile în secolul al XVIII-lea, numit şi secolul luminilor (Iluminismul). În acel moment a început un conflict real, mai ales în câmpul ideilor, între lumea transcendentă, a lui Dumnezeu, şi lumea imanentă, a omului, pentru că Dumnezeu a rămas izolat în transcendent şi omul a rămas cu lumea, în realitatea naturală, a mediului şi a lumii naturale în care trăieşte el. Acest conflict a fost determinat de motive religioase, fiind o reactie a lumii occidentale împotriva exceselor care au venit din partea inchiziției medievale.

Teologia şi ştiința au plecat pe două căi diferite. Una care vroia să facă totul dependent de Dumnezeu şi alta care vroia să facă totul dependent de om. Secularizarea nu este atât un fenomen interior, sufletesc, ci este un fenomen exterior. „Secularizarea tinde să creeze o societate fără religie”"19. „A mânca bine, a îndrăgi femei frumoase, a fura şi exploata pe cei slabi, a dormi în lenea unui trup obosit de senzații tari, a te închina icoanelor rotunde ale banului devenit în acest fel un adevărat dumnezeu făcător de minuni, iată expresia uni vieți pentru care a trudit o lume întreagă de milenii’’20.

În momentul în care rupi totul cu Dumnezeu, devii om lumesc, în locul virtuților apar patimile. Fenomenul secularizării s-a răsfrânt şi asupra persoanei lui Hristos Însuşi şi s-a ajuns să se vorbească mai mult de Iisus, care este om pe pământ şi se uneşte cu Dumnezeu numai în cer. Sectele nu cântă „Hristos a Înviat!”.

Acum Biserica are datoria să arate pericolele secularizării şi să ofere soluția care o găsim în Sfânta Scriptură. Revelația rămâne aceeaşi totdeauna, pentru că ea vine de la Dumnezeu, dar se exprimă în fiecare veac prin cultura vremii. Biserica trebuie să îşi asume şi

\footnotetext{
${ }^{18}$ Dumitru Popescu, Despre originile secularizării, interviu de Ciprian Bâra, publicat în "Ziarul Lumina", în 25.05.2008, p. 1.

${ }^{19}$ Mihai Himcinschi, Biserica în societate. Aspecte misionare ale Bisericii $\hat{\imath} n$ societatea actuală, Alba-Iulia, Edit. Reîntregirea, 2006, p. 118.

${ }^{20}$ Ernest Bernea, Îndemn la simplitate, Bucureşti, Edit. Anastasia, 2005, p. 15 .
} 
cultura vremii şi să fie la curent cu toate mijloacele de exprimare ale adevărului, dar nu trebuie să facă niciodată un compromis între teologie şi cultură. Divinitatea lui Hristos este elementul fundamental care dă forță, ca nu eu să-L modific pe Hristos, ci El să mă modifice pe mine.

Mişcarea ecumenică actuală a făcut posibilă o reafirmare mai articulată a identităţii fiecărei Biserici locale. Identitatea se poate întoarce împotriva ei însăşi dacă nu este corectată, completată şi reconciliată cu alte forme de identitate.

Bisericile din România îşi păstrează identitatea lor confesională, liturgică şi culturală, având spaţiul lor pastoral, misionar şi social bine definit, într-un climat ecumenic pozitiv. Bisericile au găsit aşadar, un echilibru adecvat între integritatea lor internă şi solidaritatea lor externă, între limbajul confesional şi cel ecumenic. Acestea au descoperit noi căi, noi posibilități şi situaţii de a fi împreună, de a acționa şi de a discuta împreună. Evoluția socială şi culturală a țării nu este un fapt „extern”, ci se reflectă în evoluția internă a Bisericilor.

\section{Exigențele misiunii în societatea şi spiritualitatea ortodoxă}

Sfầnta Liturghie este structura de comuniune şi înaintare împreună a credincioşilor spre Împărăţia lui Dumnezeu, dar şi „locul şi mediul prin excelenţă în care creştinii se pregătesc pentru misiune"21.

Nevoile omului sunt aceleaşi, doar că nivelul de percepție diferă de la o epocă la alta. Dar cu siguranță că ceea ce azi înseamnă ceva modern, în viitor va fi doar ceva demodat şi de neînțeles pentru omul viitorului, cum am putut să considerăm aşa ceva modern şi comod.

La fel şi raportul dintre omul contemporan şi Dumnezeu. Acest raport nu trebuie să fie unul modern, ci doar actual şi în armonie cu Învățătura Sfinților Părinți. Aşa cum cuvintele Sfintei Scripturi sunt

${ }^{21}$ Valer Bel, Misiunea bisericii în lumea contemporană, Cluj-Napoca, Edit. Renaşterea, 2010, p. 371. 
mereu actuale, şi pentru cei de acum 100 de ani şi pentru cei de azi, tot aşa legătura dintre om şi Dumnezeu trebuie să fie universal aceeaşi. Dumnezeu este veşnic, nedemodat, mereu actual, în permanentă legătură cu întreg neamul omenesc.

Parohia ortodoxă astăzi trebuie să pună în evidență imaginea unei comunități care invită pe toți membrii ei să-şi realizeze ca atare chemarea şi talentul lor propriu.

Ritmul parohial este impus de ritmul liturgic. În actul liturgic, creştinii sunt, pe de o parte, traşi din lume, pentru că nu sunt din lume, pe de altă parte, că sunt trimişi în lume, deoarece lumea trebuie să fie sfințită prin ei. Pe de o parte, Biserica este o "instituție", cu identitatea ei proprie, pe de altă parte, ea este în mişcare, în situație de pelerinaj, căutând cetatea viitoare (Evr. 13, 14). De altfel, eclesiologia actuală înclină din ce în ce mai mult spre înțelegerea comunității creştine ca o realitate calitativă, ca o instituție având o chemare şi slujire divină unică. Biserica are o vocație de slujire nu pentru că lumea are nevoie de serviciile ei, ci pentru că Dumnezeu o cheamă şi trimite la această slujire în lume în numele Său.

Astfel, având ca sursă Liturghia bisericească, parohia desfăşoară o întreită activitate: de hrănire sau pastorală, de mărturie sau misionară, de slujire sau diaconală. Parohia este un organism viu, o comunitate vie, în continuă "zidire şi innoire".

Participarea mirenilor la viața parohiei este plină de sens eclesiologic. Biserica este una "pentru că, voi toți, una sunteți în Hristos lisus" (Gal. 3, 28).

Vocația misionară a Bisericii ține de caracterul ei apostolic, de apostolicitatea ei. Biserica este o comunitate mesianică în care apostolii au primit, după învierea lui Iisus Hristos, autoritatea şi puterea de a fi "martorii" Săi: "Voi veți primi putere, când Se va pogorî Duhul Sfânt peste voi şi-Mi veți fi martori în Ierusalim, în toată Iudeea, în Samaria şi până la marginile pământului."(F. Ap. 1, $8)$.

Biserica consideră că o societate realmente universală trebuie să urmărească unirea tuturor oamenilor iubitori de adevăr. Lumea de 
astăzi pe de o parte progresează, pe de alta, sub raport religios, trăieşte şi anumite fenomene de criză.

Cultura se secularizează şi circumscrie interesul oamenilor la lumea de aici. Toate aceste lucruri constituie mândria omului contemporan. Şi totuşi, pe lângă şi în afară de ceea ce oamenii de cultură şi mentorii civilizaţiei moderne numesc renaştere şi progres, teologii identifică şi unele simptome de criză. Într-o lume suficientă sieşi, desacralizată, nu mai este loc pentru omul lui Dumnezeu.

Multor oameni religia li se pare că e o poveste de adormit copiii. Cei mai mulți dintre ei gândesc despre Dumnezeu, dar Sfânta Scriptură şi Biserica li se par complet învechite, irelevante pentru viața lor şi ei nu le pot lua în serios.

Omul se transformă citind Sfânta Scriptură. Dacă nu se transformă, el primeşte doar câteva noțiuni, câteva cunoştințe naturale, care de altfel nu folosesc singure prea mult.

Oricât am privi de admirativ la omul zilelor noastre, el are nevoie de câteva calități care ar putea fi considerate învechite. Dar fără ele, nu poate fi numit creştin, iar viața de creştin o să-i rămână necunoscută. Una dintre ele este dobândirea şi exersarea discernământului duhovnicesc.

Trăim astăzi într-un veac plin de haos şi dezintegrare intelectuală.

„Totul începe de la familie şi de la educaţia celor şapte ani de acasă. Aceasta este criza zilelor noastre. Piere sfințenia căsătoriei, piere legătura dintre căsătorie şi naşterea de prunci. Familii destrămate, copii lăsaţi de izbelişte - atunci când nu au fost ucişi înainte de a se naşte -, adolescență maculată, tinerețe incertă, căminul cultural înlocuit cu discoteca, guma de mestecat înlocuită cu drogul, cartea înlocuită cu televizorul, meciul de fotbal unde se joacă mai puțin cu mingea şi mai spectaculos cu pumnii şi bâtele, o lume în care indecența, vulgaritatea, parvenitismul şi corupția devin instituții ale binelui comun"22.

${ }^{22}$ Bartolomeu Valeriu Anania, Pastorală la Naşterea Domnului, Cluj Napoca, Renaşterea, 2007, p. 7. 
Împlinirea revelaţiei este Iisus Hristos, iar cuvântul Lui este viu: „Fără Mine nu puteți face nimic.”(In. 15,5). Este pretutindeni, însă noi suntem îndemnaţi să-L primim şi în sufletele noastre, priveghind asemeni fecioarelor celor înțelepte, aşteptând sosirea Mirelui Ceresc la ceas de taină.

Tot apelul „Evangheliilor rivale” din zilele noastre este faptul că oferă un fel de pseudo-teologie, un sistem de pseudo-dogme. Ele sunt primite cu bucurie de cei care nu pot găsi nici o teologie în teologia redusă la stilul „modern”.

Epoca a dogmatismului şi pragmatismului s-a sfârşit. Prin urmare slujitorii Bisericii trebuie să predice din nou doctrine şi dogme - Cuvântul lui Dumnezeu. ${ }^{23}$ „Putem spune că teologia veritabilă de astăzi nu constă în multa citire sau în multa erudiție, ci în înțelegere." Suntem chemați nu să înviem un creştinism adevărat, ci să trăim un creştinism adevărat, pentru că dacă Dumnezeu este mereu actual, înseamnă că şi viaţa în Hristos este la fel de actuală, ieri, astăzi şi în veci.

Biserica a reprezentat de-a lungul timpului o stâncă în această lume schimbătoare şi trecătoare. Credincioşii din țara noastră au încredere în rolul ei salvator şi în acei preoți care au fost şi sunt adevărații "apostoli" ai neamului. Familia are o importanță majoră, în societatea modernă secularizată şi, din ce în ce mai mult, văzând că raționalismul educațional a eşuat sau, mai trist, are efecte nocive asupra societăţii (delicvența juvenilă este într-o continuă creştere), părinții îşi îndreaptă din ce în ce mai mult atenția asupra posibilității realizării educaţiei şi cu sprijinul principiilor catehetice ale Bisericii. Iată de ce efectele secularizării asupra societății româneşti contemporane trebuie privite cu toată responsabilitatea, astfel încât viața familiei să nu fie perturbată, ci să ofere pe mai departe sprijinul necesar omului modern, înțeles ca persoană aflată în permanentă legătură cu Creatorul său.

Adevărata viaţă comunitară creştină decurge, astfel, din comuniunea şi participarea la harul necreat al lui Dumnezeu,

${ }^{23}$ Ibidem, p. 20. 
împărtăşit prin cultul divin, care devine o „matrice” a vieții în Hristos. Integrarea în „trupul lui Hristos” este o premisă esențială a mântuirii, pentru că nimeni nu se mântuieşte singur, individual, ci doar în comuniune cu frații lui în umanitate. De aceea,

„niciodată cultul nu a fost pentru Biserică o chestiune «spiritualistă» şi idealistă sau o simplă adunare religioasă, cum este înțeles astăzi din cauza alienării de-a lungul veacurilor a caracterului său, ci el este legat în chip nemijlocit de problemele vieții, la care se referă întotdeauna rugăciunile Bisericii”,24.

\section{Bibliografie}

1. Bartolomeu, Valeriu Anania, Pastorală la Nașterea Domnului, 2007.

2. Bel, Valer, Misiunea bisericii în lumea contemporană, Cluj-Napoca, Edit. Renaşterea, 2010.

3. Bel, Valer, Unitatea bisericii în teologia contemporană. Studiu interconfesional-ecumenic, Cluj-Napoca, Edit. Limes, 2003.

4. Bernea, Ernest, Îndemn la simplitate, Bucureşti, Edit. Anastasia, 2005.

5. Bria, Ioan, Dicționar de teologie ortodoxă, Bucureşti, Edit. Institutului Biblic şi de Misiune a Bisericii Ortodoxe Române, 1994.

6. Cornițescu, Emilian, Rugăciunea, în „Glasul Bisericii”, Anul L, nr. 4-6, iulie-decembrie, 1991.

7. Evdochimov, Paul, Iubirea nebună a lui Dumnezeu, Bucureşti, Edit. Anastasia, 1993.

8. Himcinschi, Mihai, Biserica în societate. Aspecte misionare ale Bisericii in societatea actuală, Alba-Iulia, Edit. Reîntregirea, 2006.

9. Himcinschi, Mihai, Doctrina trinitară ca fundament misionar. Relația Duhului Sfânt cu Tatăl şi cu Fiul în teologia răsăriteană şi apuseană, Alba-Iulia, Edit. Reîntregirea, 2004.

10. Leb, Ioan-Vasile, Biserica ortodoxă şi societatea civilă, în vol. "Religia şi societatea civilă”, vol. coordonat de Mircea Flonta, Hans Klaus Keul şi Jörn Rûsen, Bucureşti, Edit. Paralela 45, 2005.

11. Metallinos, Gheorghios D., Parohia - Hristos in mijlocul nostru, traducere de Ioan Ică, Sibiu, Edit. Deisis, 2004.

12. Mihăiță, Nifon, Misiologie creştină, Edit. ASA, 2002.

${ }^{24}$ Gheorghios D. Metallinos, Parohia - Hristos în mijlocul nostru, traducere de Ioan Ică, Sibiu, Edit. Deisis, 2004, pp. 47-48. 
13. Mihăiță, Nifon, Misiologie Creştină, Edit. Universității Valahia din Târgovişte, 2001.

14. Popescu, Dumitru, Despre originile secularizării, interviu de Ciprian Bâra, publicat în "Ziarul Lumina", în 25.05.2008.

15. Popovici, Iustin, Omul şi Dumnezeu-Om, Abisurile şi culmile filozofiei, traducere Ioan Ică şi Ioan Ică jr., Sibiu, Edit. Deisis, 1997. 